\title{
Nanoparticles for active combination radio mitigating agents of Zinc Coumarate and Zinc Caffeiate in a rat model
}

Mostafa A. Askar

Egyptian Atomic Energy Authority

Mona S. Guida

Mansoura University Faculty of Medicine

Seham. M. AbuNour

Atomic Energy Authority

Essam A. Ragab

Atomic Energy Authority

Eiman N. Ali

Atomic Energy Authority

Nadia Abdel-Magied ( $\square$ nanyabdelmagid@yahoo.com )

Egyptian Atomic Energy Authority https://orcid.org/0000-0002-9726-762X

Nahla. A. Mansour

Petroleum Research Institute

Samir A. Elmasry

Sadat City

\section{Research Article}

Keywords: radiomitigators, nanoparticles, antioxidants, DNA damage, rats.

Posted Date: June 3rd, 2021

DOI: https://doi.org/10.21203/rs.3.rs-177312/v1

License: (1) (1) This work is licensed under a Creative Commons Attribution 4.0 International License. Read Full License 


\section{Abstract}

Zinc Coumarate and zinc caffeiatenano-particles (ZCoNPs, ZCaNPs) have been shown to affectthe different biological processes. This work was undertaken to evaluate the mitigating action of ZCoNPs in combination with ZCaNPsagainst liver damage induced by gamma rays ( $\gamma$-rays). Rats were exposed to $7 G y$ of $Y$-rays, and theninjected intraperitoneally (i.p.) with ZCoNPs [2U / rat / day $(5 \mathrm{mg} / \mathrm{kg})]$, and ZCaNPs [2U / rat / day $(15 \mathrm{mg} / \mathrm{kg})]$ for 7 consecutive days. The results showed that irradiated rats treated with ZCoNPs ( $5 \mathrm{mg} / \mathrm{kg} /$ body weight) in combination with ZCaNPs ( $15 \mathrm{mg} / \mathrm{kg} /$ body weight) for 7 days revealed a significant increase in the body weight, antioxidants levels, T Helper (CD4) Cell and T Cytotoxic (CD8), associated with amarked decrease in the level of lipid peroxidation (LP), nitric oxide(NOx), total free radicals concentrate (TFRC), and DNA fragmentation. Moreover, positive alterations in the morphological state, hematological parameters, and thecell cycle phases were noticed. Additionally, the histopathological study demonstrated an improvement in the liver tissue of irradiated rats after treatment.Thus, ZCoNPs and ZCaNPscould be usedas a natural mitigating agent to reduce the hazards of ionizing radiation.

\section{Introduction}

lonizing radiation (IR) considersas a physically powerful agent to cause heritable changes in the cells; nevertheless, it is as well applied in the diagnosis and treatment of human diseases (Elgazzarand Kazem,2006).IR may lead to cancer, death, and neural dysfunction in humans and animals. It can separatethe lasting attraction between atoms, ions, or moleculesand generates ionization ofcrucial macromolecules like nucleic acids, membrane lipids, and proteins(Lavelle and Foray,2014), resulting in reactive oxygen species (ROS), which participate in the damage of the normal cell and also induces $T$ cells, decrease in the levels of T helper[cluster of differentiation 4 (CD4)] and T cytotoxic [cluster of differentiation 8 (CD8)], and also induced DNA damage (Gao et al. 2018).

Radioprotectors and radiomitigatorsare substances had been confirmed to alleviate the damage induced by radiation exposure (Citrin et al. 2010).Plants and their extractsused as phytotherapyagainst various pathologies (Ferreira et al. 2014).Phenolic compounds like Para coumaric acid (P-CAs) and caffeic acid (CAs)are involved in different pathophysiological mechanisms(Zeb 2020).

P-CAs and CAs are carbon-hydrogenbondscompounds that are hydroxyl derivatives of cinnamic acid, having antioxidant, anti-inflammatory, and anti-carcinogenic effects (An et al. 2010;Pragasam et al. 2013; Kilani-Jaziriet al. 2017; Benbettaieb et al. 2018; Kheiry et al. 2019;Sabitha et al. 2019;Agunloye et al. 2015;Choi et al. 2019; Kianmehr et al. 2020). Furthermore, previous studies reported their protective properties in the hepatic and renal cellsagainst oxidative injury (EkinciAkdemir et al. 2017; Tsai et al. 2017).

Nanotechnology isthe treatment and production of materials on the size of atoms and has possible applications in a wide range of sectors, from energy, materials electronics, optics, and remediation, to 
food, cosmetics, and medicine (Jeevanandam et al., 2018). The natural radiomitigators in nano form are achieving better stability, lower toxicity, and better penetration and distribution into the tissue (Krokosz et al. 2016).

Thus, the current studyplanned to assess the mitigating role of naturalradiomitigatorcompound, which is Zinc Coumarate (ZCoNPs) in combination with Zinc Caffeiate (ZCaNPs) nanoparticles against liver damage induced by gamma rays in the rats. This purpose has been achieved by the determination of antioxidant and oxidant markers, DNA damage, T helper (CD4) and T cytotoxic (CD8), blood parameters, and cell cycle phases. The results are confirmed by the histopathological study in the liver tissues.

\section{Material And Methods}

\section{Chemicals}

Acids of P-coumarate and Caffeiate were purchased from Sigma chemicals, Saint Louis, MO, USA.

\section{Gamma rays}

Whole-body $\mathrm{Y}$-ray to rats was made at the National Centre for Radiation Research and Technology (NCRRT), Cairo, Egypt, using Canadian ${ }^{137} \mathrm{Cs}$ (half-life time 30.719 years) Gamma Cell-40 biological irradiator with the energy of $662 \mathrm{KeV}$, and activity of $46625 \mathrm{GBq}$ (equal to $1260 \mathrm{Ci}$ ). The rat's whole body was irradiated with a single dose of $7 \mathrm{~Gy}$ and the dose rate was $0.006 \mathrm{~Gy} / \mathrm{s}$.

\section{Animals}

Male adult Wistar albino rats weighing $150 \pm 5 \mathrm{~g}$, were gained from the animal house belonging to the (NCRRT), Cairo, Egypt. Animals were maintained among typical circumstances and were exposed to a standard conditionof food and water. Rats were preserved under a controlled illuminationstate (light: dark, $13 \mathrm{~h}: 11 \mathrm{~h}$ ).

\section{Ethics approval}

The animals' treatingprocedure has been accepted by the animal ethics committee of the NCRRTsubsequent to the3Rs principles for animal experimentation and is prepared by Central Scientific Publishing Committee, Egyptian Atomic Energy Authority. Rf. (190) - 7/07/2020.

Rats were injected intraperitoneally with ZCoNPs [2U / rat / day $(5 \mathrm{mg} / \mathrm{kg})]$, and ZCaNPs $[2 \mathrm{U} / \mathrm{rat} /$ day (15 mg/kg)] (EkinciAkdemir et al. 2017; Pari and Prasath 2008).

\section{Experimental design}

Rats were separated into fourgroups (8 rats each) as follows. Group1(Control):normal healthy rats. Group2 (ZCoNPs + ZcaNPs): rats were injected with zinc Coumarate nanoparticles ( $5 \mathrm{mg} / \mathrm{kg} / \mathrm{body}$ weight) combined withzinc Caffeiate nanoparticles (15 mg/kg/ body weight). Group3 (IR): the whole 
body of rats was irradiated with a single dose of $7 \mathrm{~Gy}$. Goup4 (IR+ZCoNPs+ZCaNPs): rats were irradiated with $7 \mathrm{~Gy}$ of $\mathrm{Y}$ - rays and then were injected with zinc coumarate nanoparticles ( $5 \mathrm{mg} / \mathrm{kg} / \mathrm{body}$ weight) combined with zinc Caffeiate nanoparticles $(15 \mathrm{mg} / \mathrm{kg} /$ body weight) for seven consecutive days.

\section{Samples Preparation}

Animals were under urethaneanesthetic $(1.2 \mathrm{~g} / \mathrm{kg}$, i.p.); then post 7 days of irradiation and a fasting period of $12 \mathrm{~h}$, blood was collected by the sterilized syringe from the heart puncture. The first part of the blood will be collected in heparin and ethylenediaminetetraacetic acid (EDTA) tubes; the second part was centrifuged at $4000 \times \mathrm{g}$ for $15 \mathrm{~min}$ to obtain serum for the biochemical study. Then, animals were killed, and the liver wascut, washed in the saline, weighed, and 10\% (w/v) tissue homogenates were made in 0.1 M phosphate buffer ( $\mathrm{pH}$ 7.4) by Teflon homogenizer (GlasCol, Terre Haute, IN, USA). The supernatant result was centrifuged at $10,000 \times g$ for the biochemical study.

\section{Preparation of Zinc Coumarate Nano Particles (ZCoNPs)}

$1.2 \mathrm{~g}$ of $(\mathrm{NaOH})$ was dissolved indistilled water, and then $5 \mathrm{~g}$ of $\mathrm{p}$ - coumaric acid was added and the reaction mixture was reservedover stirring on a hot plate to complete the formation of sod. Coumarate $4.1 \mathrm{~g} \mathrm{ZnCl} 2$ was solved in distilled water, and followed by sod. Coumarate addition to obtain yellow precipitate from zinc coumarate that was separated by filtering and then rinsing and drying in the oven. Zinccoumarate powder was crushed in the mill to convert into nanoscale material (Charkhi et al., 2010).

\section{Preparation of Zinc Caffeiate Nano Particles (ZCaNPs)}

$1.11 \mathrm{~g}$ of $(\mathrm{NaOH})$ was dissolved in purified water, then $5 \mathrm{~g}$ of caffeic acid was added and the reaction mixture was kept under stirring on a hot plate to form sod.caffeiate. $3.78 \mathrm{~g} \mathrm{ZnCl} 2$ was dissolved in distilled water, and then added to sod.caffeiate to form yellow precipitate from zinc caffeiate, which was separated byfiltering and washing to dry in the oven. Zinc caffeiate powder was groundin the ball mill to convert into nano scale material (Charkhi et al., 2010).

Verification of ZCoNPs and ZCaNPs were carried out by:

The structure of the prepared nano system was characterized by vibrating-Sample-Magnetometer (VSM); transmission-electron-microscopy (HRTEM), Fourier-transform-infrared-spectroscopy (FT-IR) and wide rang X-ray-diffraction (WAXD).

\section{Determination of Body Weight and Morphological State}

The changes in body weight and Morphological State had been recorded for all rats throughout the experimental period by the following equation:

Percent of change $=$ wt at week $(n)-w t$ at week $(0) /$ wt at week $(0) \times 100$

\section{Complete Blood Count (CBC) Determination}


Complete blood count was estimated by (Sachse and Henkel, 1996), the performance of the CELL-DYN 1700 (Abbott Diagnostics, Abbott Park, IL, USA) is a multiparameter, mechanicalhematologyanalyzer system.

\section{Antioxidantand oxidant markers Analysis}

Superoxide dismutase activity (SOD), glutathione peroxidase activity (GPx) and catalase (CAT), and glutathione content (GSH), were measured in the blood by the method of Minamiand Yoshikawa, (1979); Paglia and Valentine (1967; Aebi (1984; Beutler et al.(1963),respectively. Determination of antioxidant molecule and enzymes via commercial kits (Biodiagnostic, Egypt).Lipid peroxidation is measured calorimetrically as described by Yoshioka, (1979), and Nitric oxide (NOx) content as nitrite concentration was determined according to the method of Miranda et al. (2001), using commercial kits (Biodiagnostic, Egypt). Total free radicals were determined by the Electron Spin Resonance technique (ESR) according to Heckly (1975).

\section{ROS detection by electron spin resonance (ESR)}

This procedure is applied to investigate free radical concentrations in the biological materials through the unpaired electrons (free radicals). The method is based on an electron spinning in an outwardly applied magnetic field and absorbing enough electromagnetic radiation for a reversal of the electron spin.

Samples of blood were dehydrated in absolute alcohol by immersion for 10 minutes 5 samples/group. These materials and sediment were then oven-dried at $40^{\circ} \mathrm{C}$. After drying, the samples were carefully crushed with agate mortar and pestle for homogenization under the low impact, in order to avoid induction of other radicals by mechanical action. Subsequently, an aliquot of each sample was transferred to an ESR quartz tube, with a $3 \mathrm{~mm}$ internal diameter. The water sample was placed in a capillary tube and sealed prior to insertion in the quartz tube. The tube containing the sample was inserted into a quartz dewar for freezing with liquid nitrogen for spectrum recording (77K) (Radicals $/ g) \times 10^{17}$ ) (Leite et al. 2018). The extraction of the a-phenyl-N-tert-butyl nitrone spin adduct in ethyl acetate in order to increase its half-life time and the detection of its electron spin resonance spectrum have been described in previous reports in animal models and in human blood. The ethyl acetate extracts were transferred to a flat quartz cell and the spectrum was recorded(G Facorro, et al., 2004).

\section{Determination of DNA Damage in Liver Tissue by comet assay}

For coating glass slides with a thin layer of agarose, $35 \mu \mathrm{l}$ of $0.5 \%$ normal melting point(Sigma, St. Louis, USA).The coating solution put on a glass slide and dried with an alcohol lamp(Changsin Scientific Co., South Korea). The slide was again covered with $75 \mu$ of $0.5 \%$ NMA solution by diffusion with a slip cap and stored for $5 \mathrm{~min}$ in an ice bath to enhance gel formation. 
On pre-chip wrappers, was a mixture placed of $100 \mu \mathrm{L}$ cell suspension and $1 \%$ low melting point agarose $\left(50 \mu \mathrm{L}: 100 \mu \mathrm{L}\right.$ mixed at $45^{\circ} \mathrm{C}$ ) applied in layers by spreading it out with a sliding cover, then leave the gel in frozen water for 5 minutes.Slides were submerged in neutral lysis buffer( $0.2 \%$ SDS, $40 \mathrm{mM}$ Tris-acetate, $1 \mathrm{mM}$ EDTA, pH 8.0) for 30 min at room temperature, and rinsed by immersion in the electrical electrophoresis solution, [Tris-borate-EDTA (TBE)] (45mM Tris-borate, $1 \mathrm{mM}$ EDTA, pH 8.4). Slides were electrocuted at room temperature at $2 \mathrm{~V}, 300 \mathrm{~mA}$ for 2 minutes in a horizontal electrophoresis chamber(Hoefer, San Francisco, USA) saturated with TBE. The slides were then immersed in distilled water for 5 minutes and air to dry, and then treatedwith $100 \mu \mathrm{L}$ of a fluorescent pigment, YOYO-1 (10 $\mu \mathrm{g}$ $\mathrm{mL}-1$, Molecular Probes, Eugene, USA, fixed among a cover glass and dried for 20 min (Bhatti et al., 2012). The stained slide has been shown under fluorescent (optical microscope Olympus, Tokyo, Japan) at magnification $\times 250$ filters with exciting green. The images were transported among a Charge-coupled device (CCD) video camera to a computer and analyzed by software, Comet Assay II image analysis system (Perceptive Instruments, Suffolk, UK) to estimate the quantity of DNA migration. The tail length and the tail moment were measured as the degree of DNA damage. Two hundred cells were arbitrarily selected and calculated (two slides made for one sample, 100 randomlyselected cells per slide) from one sample. Statistical measurements were occurredby the Excel 5.0 program (Microsoft, Redmond, USA), which formed the standards of the mean tail length for a sample and the values of percentage cells in six ranges of tail length.

\section{Flow Cytometry Assays}

$1 \times 10^{6} \mathrm{cell} / \mathrm{mL}$ was produced by isolation of mononuclear cells from theblood with FicollPaquein addition Phosphate-buffered saline (PBS) buffer. 100 $\mu \mathrm{L}$ of cell suspension was put to PI buffer (propidiumiodide with RNase) and kept for at least 1 hour in the dark at $+4^{\circ} \mathrm{C}$. Post incubating, the cells were obtained by BD Flow Cytometry Accurie C6Plus (Becton Dickinson, San Diego, CA). The DNA of 10 000 cells was analyzed by FACS Caliber Flow Cytometry to estimate the percentages of cells (El Tawiil et al., 2020).Cell surface antigen expression was examined by fluorescence-activated cell sorter (FACS) analysis with the following monoclonal antibody (mAbs). FITC-conjugated anti-CD4, FITC-conjugated anti-CD8, and FITC-conjugated mouse iso type-matched control mAbs, all brought from BD Biosciences (Guida et al., 2016).Samples were repeated three times.

\section{Histopathological study}

Liversamples were taken and put in $10 \%$ buffered formalin fixationand then dehydrated, cleared and embedded in paraffin. $5 \mu \mathrm{m}$ in thickness of tissueswere prepared and stained regularly with haematoxylin and eosin due to the method of Bancroft and Stevens (1996), and investigated microscopically.

\section{Statistical Analysis}

All the standards are considered as mean \pm standard deviation (SD). Experimental data were analyzed via one-way analysis of variance (ANOVA) and then byTukey's post hoc test to assess the significant 
variations between means. The significance levels were put at $p<0.05, p<0.01$, and $p<0.001$.

\section{Results}

the zinc Coumarate nanoparticles (ZCoNPs) (Fig. 1A) ranging from 15-25 nm in diameter and has a spherical shape, while (Fig. 1B) shows The TEM image in the case of Zinc caffeinate nanoparticles (ZCaNPs) in the range of 7-12 $\mathrm{nm}$.

The FT-IR spectra of p-coumaric acid and ZCoNPssamples (Fig. 1C) are similar and show the typical bands. The band derived from stretching hydroxyl group vibrations $\mathrm{v}(\mathrm{OH})$ is located at $3385 \mathrm{~cm}^{-1}$. Bands assigned to $\mathrm{C}=\mathrm{C}$ stretches of the double bond are at $1638 \mathrm{~cm}-1$. Peaks characteristic for the aromatic ring are 1606-1428 cm-1, bands assigned to in-plane deformations of $\mathrm{CH}$ are present at $1255-1106 \mathrm{~cm}$ 1. At lower wavenumbers, peaks derived from out-of-plane deformations of $\mathrm{CH}$ are located at $974-829$ $\mathrm{cm}-1$. Peaks assigned to vibrations of carboxylate are vas (COO-) $1512 \mathrm{~cm}-1$ and vs (COO-) $1400 \mathrm{~cm}-1$. The data of FTIR spectroscopic approve the integrity of the band at $1673 \mathrm{~cm}-1$ in the FTR spectrum of pcoumaric acid disappears with the deprotonation, as can be observed in the spectrum of ZCoNPs, also, the band at $940 \mathrm{~cm}-1$ can be assigned to the $\mathrm{OH}$ bending of the carboxyl group which only appears in the p-coumaric acid spectrum.

FTIR spectrum of Caffeic acid and ZCaNPs (Fig. 1D), which appear in the region of $4000-2600 \mathrm{~cm}-1$, were assigned to the different modes of the $\mathrm{OH}$ vibrations. The high-frequency region is also characterized by the week $\mathrm{CH}$ stretching modes of benzene moiety and acyclic chain. The vibrational contributions to the normal stretching modes in the 3428-3231 cm-1 region are assigned almost solely to the $\mathrm{OH}$ and $\mathrm{CH}$ stretching modes themselves. The bands of the strong intensities at 1645 were assigned to the $\mathrm{CO}$ stretching modes of the carboxyl group. In addition, the bands of the intensities in the IR spectrum at $1616 \mathrm{~cm}-1$ assigned to the $\mathrm{C}=\mathrm{C}$, and $1450 \mathrm{~cm}-1$ was mostly assigned to the $\mathrm{CC}$ stretching modes of both benzene moiety and acyclic chain. There is a slight shift due to the formation of ZCaNPs.

XRD patterns of p-coumaric acid, ZCoNPs, and ZCaNPs are shown in (Fig. 1E). It is observed the existence of the main values of $2 \theta /$ degrees of the p-coumaric acid peaks beside new peaks appear at $2 \theta /$ degrees; $15.8^{\circ}, 16.99^{\circ}$, and $27.7^{\circ}$ for zinc in ZCoNPs. These peaks are also observed in XRD patterns of ZCaNPs which confirmed their crystal structures.

(Table. 1) and (Fig. 2) showed the results of change percent in body weight and morphological state of animals. It was obvious that the percent of change in the body weight of animals exposed to $y$-rays 7Gy was greatly $(P \leq 0.001)$ reduced and deterioration of morphological state, compared to control animals.

Moreover, data showed that ZCoNPs + ZCaNPs treatment for 7 days to normal rats had no alterations $(P$ $\geq 0.05)$ in the body weight and morphological state, compared to their parallel control values. While irradiated rats treated with ZCoNPs + ZCaNPs for 7 days revealed a noticeable augment $(P \leq 0.001)$ in the percentagechange of the bodyweight and an improvement in the morphological state, compared to the irradiated rats. 
In the present work, our data demonstrated that the complete blood count (CBC) level in irradiated rats had a highlysignificant decrease $(P \leq 0.001)$ in the value of white blood cells (WBCs), lymphocyte[ LYM (RM), LYM (\%)], monocyte, monocyte (\%M ), granulocytes [GRAN(RM), GRA(NG)], red blood cells (RBCs), haemoglobin $(\mathrm{HB})$, haematocrite $(\mathrm{HCt} \%)$, [mean corpuscular volume $(\mathrm{MCV}) \mathrm{fL}$ ], mean corpuscular hemoglobin $(\mathrm{MCH})$, red blood cells distribution width RDW, platelet count test (PLT) associated with a significant elevation $(P \leq 0.001)$ in the value of mean corpuscular haemoglobin concentration $(\mathrm{MCHC})$, compared to the control normal group(Table. 2).

Furthermore, our data showed that ZCoNPs + ZCaNPs treatment for 7 days to normal rats had no marked alterations $(P \geq 0.05)$ in the level of complete blood count, compared to their parallel control values. While irradiated animals treated with ZCoNPs + ZCaNPs for 7 days revealed a marked positive modulation in the complete blood count (CBC), compared to the irradiated one.

Results of the standard alkaline comet assay are presented in (Table.3) and (Fig. 2) showed the damage of DNA manifested by a significant increase in the level of tail length, DNA in the tail, tail moment, olive tail moment, compared to their similarity values in the control rats.Further, ZCoNPs + ZCaNPs treatment to normal rats showed a significant decrease in the level of tail length, DNA in tail, tail moment, olive tail moment, compared to their values in the control rats. On the other hand, ZCoNPs + ZCaNPs treatment to irradiated rats confirmed DNA repair evidenced by a significant decrease in the tail length, \% DNA in tail, tail moment, olive tail moment, compared to their corresponding values in irradiated one.

In (Table. 4) showed a remarkable reduction $(P \leq 0.001)$ in the activity of SOD, GSHpx, and CAT and GSH content, associated with a significant elevation $(P \leq 0.001)$ in the values of NOx, LP, and TFRC in the irradiated group, compared to the normal group.

Treatment with ZCoNPs + ZCaNPs for 7 days to normal rats had no changes in the level of antioxidant enzymes and content. On the other hand, the activity of SOD, GSHpx and CAT, and GSH content displayed an obvious increase $(P \leq 0.001)$ linked with a major reduction $(P \leq 0.001)$ in the level of NOx, LP, and total FRC (Fig. 3) in the irradiated rats treated with ZCoNPs + ZCaNPs, compared to irradiated rats.

The lymphocyte population's data for CD4 T helper and CD8 T cytotoxic cells in blood were showed in (Table. 5) and (Fig. 4). The Post hoc analysis showed a significant decrease $(P \leq 0.001)$ in irradiated rats, compared to control normal rats.

Moreover, animals injected with ZCoNPs + ZCaNPs showed no significant changes $(P \geq 0.001)$ in the lymphocyte population data, compared to the irradiated group. While irradiated rats injected with ZCoNPs + ZCaNPs showed amelioration in the lymphocyte populations data appeared by a noticeable increase in the percent of CD 4 and CD8 (Table. 5 and Fig. 5), compared to the irradiated group.

Additionally, the result in the irradiated group showed that a significant decrease $(P \leq 0.001)$ in the $S$ phase and a visible elevation ( $\mathrm{P} \leq 0.001$ ), in (Sub G1 (apoptosis), G0/1, G2/M) phase compared to the normal group (Table. 6). 
Treatment with ZCoNPs + ZCaNPs to normal rats had no changes $(P \leq 0.001)$ in S phase, Sub G1 (apoptosis), G0/1, G2/M phase, compared to normal group While, the injection with ZCoNPs + ZCaNPs to irradiated animals demonstrated a significant enhancement $(P \leq 0.001)$ in $S$ phase and a remarkable decline ( $\mathrm{P} \leq$ 0.001) in (Sub G1 (apoptosis), G0/1, G2/M) phase (Table. 6), compared to the irradiated group.

The liver of a control rat under the light microscopic appeared to decompose of lobules with central veins and peripheral hepatic triads embedded in connective tissue. The sides between the cell cords are designate by blood sinusoids and covered by Kupffer cells. The hepatocytes are regular and have a large spherical nucleus with a clearly obvious nucleolus and peripheral chromatin distribution and bi-nucleated cells were also appeared (Fig. 5A).

(Fig. 5B) showed that normal rats treated with ZCoNPs+ZCaNPs revealed no significant change, while, the liver of irradiated rats showed noticeable degenerative alterations in most liver cells; the cells were expanded and contain light and foamy cytoplasm packed with plentiful vacuole-like areas. The walls of the blood sinusoids were dilated and showed abundant Kupffer cells. The $y$-irradiation also revealed signs of hepatocytes necrotic changes with pyknotic nuclei and hepatocytes degeneration with strongly acidophilic cytoplasm. Diffused hemorrhagic areas and interstitial edema were observed (Fig. 5C). There are no pathological changes in the Irradiated+ZCoNPs+ZCaNPs group, which showed a normal lobular manner with central vein and radiating hepatic cords (Fig. 5D).

\section{Discussion}

Radiation motivatesa remarkable change in the metabolic series actionsresulting in oxidative stress that is involved in the process of carcinogenesis and different diseases (Liguori et al., 2018;Yahyapour et al., 2018). The damage induced by radiation in the biological organs might be by the direct impact of radiation on DNA, RNA, proteins, and lipids or indirectly by the radiolysis of water and the generation of excess ROS, which has been confirmed the mechanisms of IR-induced cytotoxicity (Khan et al., 2018).

Data from the current study exhibited that irradiated rats treated withZCoNPs in combination with ZCaNPs showed a marked improvement in the liver manifested by a positive modulation in the percentage change of body weight and morphological state, oxidative and antioxidant markers as well as in DNA damage, CD4, CD8, blood parameters and cell cycle.

The results are in concordance with the work of Takahashi et al. (2020) who reported a loss of body weight in rats post-irradiation. However, ZCoNPs in combination with ZCaNPs, a natural nanoprotector is considered as a targeting mediator for preventing free radical damage that might be due to its effect in the catabolic of radiation.

Irradiation induces direct disorder of the circulatory system resulting in hemorrhage and diminishes cell formation (Hamada et al. 2020). In the present study, the observed decreased levels of hematological parameters in the irradiated rats indicating an anemic condition, and the reduction could be caused by 
the direct injuryinduced by a lethal dosage of gamma rays (Bala et al. 2019).The cellular parameters of the blood are mainly susceptible to oxidative stress according to a high ratio of polyunsaturated fatty acids (PUFA) in their membranes inducing membrane lipid peroxidation, leading to membrane rigidity, cellulardeformability, reduce erythrocyte survival (Adams et al. 2015).

Moreover, the reduction in the hemoglobin content might be assigned to thereduction in the number of red blood cells and hemorrhage. Additionally, the decrease in the hematocritvalue might result from erythropoietin decrease, destruction of mature cells, or increased plasma volume.Further, the lowering in the values of blood components after gamma rays exposure might due to a bone marrow syndrome (Green and Rubin 2014; Taqi et al. 2019).

Following ZCoNPs and ZCaNPs injection to irradiated rats, the alterations of haematological parameters might be attributed to its free radical scavenging and RBCs and its related indices were considerably improved. Besides, the result might be occurred via stimulating formation or secretion of erythropoietin, which stimulates stem cells in the bone marrow of rats to produce new RBCs (Choi et al. 2019; Kianmehr et al. 2020).

In the current study, we have recorded a drop in the activity of SOD, GPx and CAT, and GSH content, which might be due to radiation-induced impair in the antioxidant defense mechanism and the decreased antioxidant levels might be due totheir utilization by the enhanced rising of ROS (Prasad et al. 2005; Kurutas 2016).

The antioxidant response element (ARE) mediates the transcriptional activation of many genes which is upstream of many phase II detoxification and antioxidant enzymes in response to oxidative stress. Furthermore, SOD, GPx and CAT genes are considered to be regulated with such kind antioxidant response elements (Saha et al. 2020). So we suggest that ZCoNPs in combination with ZCaNPs arrive at the transcriptional agents and stimulate the gene expression during cell oxidation resulting in an augment in the synthesis of the antioxidant enzyme such as blood SOD, GSH, GPx, CAT (Kanagaraj et al. 2015).It is well documented thatP-coumaric and caffeicacids have the ability tostimulate the activity of phase II detoxicationenzymes and oxidative stress inhibition (Chen et al. 2020). The location of the hydroxyl groups in the ZCoNPs and ZCaNPs might share in the stimulation of $y$-glutamyl cysteine synthase, the rate-limiting enzyme implicated in the glutathione production (Lee et al. 2016).

High concentration levels of nitric oxide (NO) have a mutual negative relationship with tissue function and are implicated in diverse physiological and pathological functions (de Oliveira et al. 2017). Endothelial nitric oxide synthase (eNOS), neuronal NOS (nNOS), and inducible NOS (iNOS) is dependent on the binding of calmodulin that is affected by calcium levels in the cells (Weissman et al. 2002).Thereby, we suggest that increased calcium levels due to radiation exposure (Nuszkiewiczet al. 2020) might be led to increased binding of calmodulin to isoforms of NOS, resulting in a transient increase in NO production by these enzymes (Silva and Ballejo 2019). Moreover, gamma rays might increase the endogenous NO production by direct DNA impairment, which motivate poly ADP-ribose polymerase (PARP) that in turn excite the activation of nuclear factor kappa B (NF-KB) to end with an 
increase of the iNOS expression and NO formation (Wilson et al. 2019). ZCoNPs and ZCaNPs treatment post- radiation was established to diminish the lipid peroxidation and NOx that might be attributed to their source of cysteine, which can stimulate the synthesis of GSH protecting the body against cell oxidation (Smith et al. 2017).

Our study demonstrated that $\gamma$-rays induced an excessof free radicals can produce DNA damage, and permanent impairment, signal transduction pathways alterations, cytogenetic and biochemical defects(Prasad et al. 2005).DNA impairment might be attributed to an increased concentration of vasoconstrictors, or due to a decline of vasodilators like NO.On the other hand, our data showed that ZCoNPs in combination with ZCaNPs have the ability to mitigate the damage of DNA or fragmentation against oxidative damage induced by singlet oxygen (Reza et al. 2016). This is in concordance with Srinivasan et al who reported that curcumin is a part of the natural compound ZCoNPs and ZCaNPs, protecting DNA by reducing the chromosomal aberrations (Srinivasan et al. 2007).

The impaired immunological function might result from immune system impairment. The response of the immune system might be due to the action of $T$ cells lymphocytes originated in the thymus. $T$ lymphocytes comprise Cytotoxic T cells (CD8), which respond to cells and are affected by viruses or tumor cells; T helper cells (CD4)produce mediators to stimulate lymphocytes; B cells; macrophages; natural killer cells, and the T cells themselves (Li et al. 2015).

Herein, exposure to ionizing radiation, lymphocytes die via apoptosis. Besides, a decrease of CD4 and CD8 level were found in the current work and this is in concordance with Li et al. (2015).Our data displayed that irradiated rats treated with ZCoNPs and ZCaNPsprotect CD4 and CD8 from the hazard of Y-ray and this is similar with Pragasam et al. (2013);Choi et al. (2019).

In this study, irradiated rats showed a high level of cell death induction, where the number of cells in the G0/1phase, S phase, and the cell cycle weremarkedly decreased but the cells in the sub G1 phase (apoptosis) and G2/M phase were significantly increased. This result might be caused by the induction of apoptosis (Vucic et al. 2006; Durante and Formenti 2018).

Otherwise, the results showed that the treatment with ZCoNPs and ZCaNPs post- radiation mitigated the cell cycle phases resulted from the risk of $\mathrm{y}$-ray and this is in agreement with Rosa et al. (2018).

Moreover, our data demonstrated that the liver of ratsexposed to gamma rays resultedin diverse lesions with dilated blood vessels and pyknosis, hemorrhage, vacuolation, and necrobiotic alterations in the hepatocytes. Similar results were recognized to that in (Zavodnik et al. 2003); Guryev 2005). Additionally, tissue of irradiated rats showed fibrosis, which is the most commondelayed effect of radiation, a lack of parenchymal hepatocytes, and deformation of the lobular architecture associated with both per-central and per-portal fibrosis (Yıldızhan et al. 2020).

Irradiated rats treated with ZCoNPs and ZCaNPscould attenuate the adverse effects of $y$ - radiation exposure and similar results reported by Pang et al.(2016). It should be considered that the mitigating 
impact of ZCoNPs and ZCaNPs against hepatotoxicity might be dependent on the antioxidant effect (Ali and Zeyadi 2020).

\section{Conclusion}

The present study suggests that ZCoNPs in combination with ZCaNPs treatment could be used as radiomitigators in the treatment of harmed hepatic tissues induced by radiation. The treatment of irradiated rats showed a positive modulation inthe marker of antioxidant and oxidant parameters, blood elements, DNA, CD4, CD8, and cell cycle phases. Additionally, the results were confirmed by the histopathological study, which exhibited an improvement in the liver tissues of rats.

\section{Declarations}

\section{Author contributions}

All authors planned the experiment. Askar MA, Mansour NA,Ali EN, Abdel-magiedN,Ragab EA prepared the samples of tissues and nanoparticles. GuidaMS prepared the samples of electrophoresis. Abu NourSM prepared the samples forhistopathologicalstudy; ElmasrySA prepared the samples for Flow Cytometry study. All authors analyzed the data. All authors read and approved the final manuscript.

Funding no financial relationships relevant to this study

Data availability Data are available on request to the authors

\section{Compliance with ethical standards}

Conflict of interest: The authors declare that they have no conflict of interest.

Ethical approval: The animals' treating procedure has been accepted by the animal ethics committee of the NCRRT subsequent the 3Rs principles for animal experimentation and is prepared by Central Scientific Publishing Committee, Egyptian Atomic Energy Authority. Rf. (190) - 7/07/2020.

Consent to participate: All authors contributed voluntarily to this study.

Consent to publish: All authors have consent for the publication of the manuscript.

\section{References}

Adams F, Bellairs G, Bird AR, OguntibejuOO(2015) Biochemical storage lesions occurring in nonirradiated and irradiated red blood cells: a brief review. BioMed Res Int 2015:8.

Aebi H. (1984) Catalase in vitro. Methods Enzymol 5:121-126. 
Agunloye OM, Oboh G, Ademiluyi AO, Ademosun AO, Akindahunsi AA, Oyagbemi AA, et al. (2019) Cardioprotective and antioxidant properties of caffeic acid and chlorogenic acid: mechanistic role of angiotensin converting enzyme, cholinesterase and arginase activities in cyclosporine induced hypertensive rats. Biomed Pharmacother 109: 450-458.

AliEMM and Zeyadi MA (2020) Impact of caffeic acid phenylester on nitric oxide synthase and arginase in rats intoxicated with nitrites. Journal of King Saud University - Science 32 : 2454-2461

An SM, Koh JS, Boo YC (2010) p-coumaric acid not only inhibits human tyrosinase activity in vitro but also melanogenesis in cells exposed to UVB. Phytother Res 24:1175-80.

Bala S, Chugh NA, Bansal SC, Koul A (2019) Aloe vera modulates X-ray induced hematological and splenic tissue damage in mice. Hum ExpToxicol 38:1195-1211.

Bancroft JD, Stevens AE (1996) Theory and practice of histological techniques, 4th edn. Churchill Livingstone, Edinburgh $\mathrm{p} 766$.

Benbettaieb N, Nyagaya J, Seuvre AM, Debeaufort F (2018) Antioxidant Activity and Release Kinetics of Caffeic and p-Coumaric Acids from Hydrocolloid-Based Active Films for Healthy Packaged Food. J Agric Food Chem 66:6906-6916.

Beutler E, Duron O, Kelly BM (1963) "Improved method for the determination of blood glutathione." J. Lab. Clin Med 61: 882-888.

Bhatti IA, Akram K, Kwon JH (2012) An investigation into gamma-ray treatment of shellfish using electron paramagnetic resonance spectroscopy. Journal of the Science of Food and Agriculture 92:759763.

Charkhi A, Kazemian H, Kazemeini M (2010) "Optimized experimental design for natural clinoptilolite zeolite ballnext term milling to produce previous termnanonext term powders." Powder Technology 203: 389-396.

Chen S, Lin R, Lu H, Wang Q, Yang J, Liu J, Yan C (2020) Effects of phenolic acids on free radical scavenging and heavy metal bioavailability in kandeliaobovata under cadmium and zinc stress. Chemosphere $249: 126341$.

Choi HG, Tran PT, Lee JH, Min BS, Kim JA (2019) Correction to: Anti-inflammatory activity of caffeic acid derivatives isolated from the roots of Salvia miltiorrhiza Bunge. Arch Pharm Res 42 :378.

Citrin D, Cotrim AP, Hyodo F, Baum BJ, Krishna MC, Mitchell JB (2010) Radioprotectors and mitigators of radiation-induced normal tissue injury. Oncologist 15 :360-371. 
de Oliveira GA, Cheng RYS, Ridnour LA, Basudhar D, Somasundaram V, McVicar DW, Monteiro HP, Wink DA (2017) Inducible Nitric Oxide Synthase in the Carcinogenesis of Gastrointestinal Cancers. Antioxid Redox Signal 26 :1059-1077.

Durante M, Formenti SC (2018) Radiation-Induced Chromosomal Aberrations and Immunotherapy: Micronuclei, Cytosolic DNA, and Interferon-Production Pathway. Front Oncol 8:192.

EkinciAkdemir FN, Albayrak M, Çalik M, Bayir Y, Gülçin I (2017) The Protective Effects of p-Coumaric Acid on Acute Liver and Kidney Damages Induced by Cisplatin. Biomedicines 5 :18.

El Tawiil GA, Noaman EA, Askar MA, El Fatih NM, Mohamed HE (2020) Anticancer and Apoptogenic Effect of Graviola and Low-Dose Radiation in Tumor Xenograft in Mice. Integr Cancer Ther 19:1534735419900930.

Elgazzar A.H., Kazem N (2006) Biological Effects of lonizing Radiation. In: Elgazzar A.H. (eds) The Pathophysiologic Basis of Nuclear Medicine. Springer, Berlin, Heidelberg .

Ferreira, TS, Moreira, CZ, Cária, N Z, Victoriano, G, SILVA Jr, WF, \&Magalhães, JC (2014).Phytotherapy: an introduction to its history, use and application. RevistaBrasileira de PlantasMedicinais 16: 290-298

Gao H, Dong Z, Gong X, Dong J, Zhang Y, Wei W, Wang R, Jin S (2018) Effects of various radiation doses on induced T-helper cell differentiation and related cytokine secretion. J Radiat Res 59: 395-403.

G Facorro, et al (2004). Oxidative study of patients with total body irradiation: effects of amifostine treatment, Bone Marrow Transplantation 33, 793-798.

Green DE, Rubin CT (2014) Consequences of irradiation on bone and marrow phenotypes, and its relation to disruption of hematopoietic precursors. Bone 63:87-94.

Guida MS, Abd El-Aal A, Kafafy Y, Salama SF, Badr BM, Badr G (2016) Thymoquinone Rescues T Lymphocytes from Gamma Irradiation-Induced Apoptosis and Exhaustion by Modulating ProInflammatory Cytokine Levels and PD-1, Bax, and Bcl-2 Signaling. Cell PhysiolBiochem. 38:786-800.

Guryev DV (2005) Histologic assessment of regenerating rat liver under low-dose rate radiation exposure .International Congress Series 1276: 181-182

Hamada N, Kawano KI, Yusoff FM, Furukawa K, Nakashima A, Maeda M, Yasuda H, Maruhashi T, Higashi Y (2020) Ionizing Irradiation Induces Vascular Damage in the Aorta of Wild-Type Mice. Cancers (Basel) $12: 3030$.

Heckly RJ (1975)"Biological applications of electron spin resonance. In Free Radicals in Dry Tissues." Edited by: Swartz HM, Bolton. New York: Wiley Inter ScienceJR, Borg DC: 5. 
Jeevanandam J, Barhoum A, Chan YS, Dufresne A, Danquah MK (2018) Review on nanoparticles and nanostructured materials: history, sources, toxicity and regulations. Beilstein J Nanotechnol 9:1050-1074.

Kanagaraj VV, Panneerselvam L, Govindarajan V, Ameeramja J, Perumal E (2015) Caffeic acid, a phyto polyphenol mitigates fluoride induced hepatotoxicity in rats: a possible mechanism. BioFactors 41:90100.

Khan F, Garg VK, Singh AK, Kumar T (2018)Role of free radicals and certain antioxidants the in the management of huntington's disease: a review. J Anal Pharm Res Res 7:386-392.

Kheiry M, Dianat M, Badavi M, Mard SA, Bayati V (2019) p-Coumaric Acid Attenuates LipopolysaccharideInduced Lung Inflammation in Rats by Scavenging ROS Production: an In Vivo and In Vitro Study. Inflammation 42:1939-1950.

Kianmehr Z, Khorsandi K, Mohammadi M, Hosseinzadeh R (2020) Low-level laser irradiation potentiates anticancer activity of p-coumaric acid against human malignant melanoma cells. Melanoma Res 30:136-146.

Kilani-Jaziri S, Mokdad-Bzeouich I, Krifa M, Nasr N, Ghedira K, Chekir-Ghedira L (2017) Immunomodulatory and cellular anti-oxidant activities of caffeic, ferulic, and p-coumaric phenolic acids: a structure-activity relationship study. Drug ChemToxicol 40:416-424.

Krokosz A, Lichota A, Nowak K, Grebowski J (2016) Carbon nanoparticles as possible radioprotectors in biological systems. Radiation Physics and Chemistry. 128: 143-150

Kurutas EB (2016) The importance of antioxidants which play the role in cellular response against oxidative/nitrosative stress: current state. Nutr J 15:71.

Lavelle C, Foray N (2014) "Chromatin structure and radiation-induced DNA damage: From structural biology to radiobiology". International Journal of Biochemistry \& Cell Biology 49: 8497.

Lee HY, Kim SW, Lee GH, Choi MK, Jung HW, Kim YJ, Kwon HJ, Chae HJ (2016) Turmeric extract and its active compound, curcumin, protect against chronic $\mathrm{CCl}_{4}$-induced liver damage by enhancing antioxidation. BMC Complement Altern Med 16,316.

Leite L A R, Kinoshita A, Baffa O, Azevedo R K, Abdallah VD(2018) Electron Spin Resonance (ESR) in detection of aquatic pollution through host-parasite relationship. Rev. Ambient.Água [Internet]. 2018 [cited 2021 Mar 17]; 13(6): e2085.

Li HH, Wang YW, Chen R, Zhou B, Ashwell JD, Fornace AJ Jr (015) lonizing Radiation Impairs T Cell Activation by Affecting Metabolic Reprogramming. Int J BiolSci 11:726-36. 
Liguori I, Russo G, Curcio F, Bulli G, Aran L, Della-Morte D, Gargiulo G, Testa G, Cacciatore F, Bonaduce D, Abete $\mathrm{P}$ (2018) Oxidative stress, aging, and diseases. ClinInterv Aging 13:757-772.

Minami M and Yoshikawa H (1979)"A simplified assay method of superoxide dismutase activity for clinical use." ClinChimActa 92: 337-342.

Miranda KM, Espey MG, Wink DA (2001)A rapid simple spectrophotometric method for simultaneous detection of nitrate and nitrite. Nitric Oxide 5:67-71.

Nuszkiewicz J, Woźniak A, Szewczyk-Golec K (2020) lonizing Radiation as a Source of Oxidative StressThe Protective Role of Melatonin and Vitamin D. Int J MolSci 21:5804.

Paglia DE, Valentine WN (1967) Studies on the quantitative and qualitative characterization of erythrocyte glutathione peroxidase. J LaboratClinMed 70:158-169.

Pang C Zheng Z Shi L Sheng Y Wei H Wang Z JiL (2016)Caffeic acid prevents acetaminophen-induced liver injury by activating the Keap1-Nrf2 antioxidative defense system. Free Radical Biology \& Medicine 91:236-246.

Pari $L$ and Prasath A (2008) "Efficacy of caffeic acid in preventing nickel induced oxidative damage in liver of rats." ChemBiollnteract 173: 77-83.

Pragasam SJ, Venkatesan V\&Rasool M (2013) Immunomodulatory and Anti-inflammatory Effect of pCoumaric Acid, a Common Dietary Polyphenol on Experimental Inflammation in Rats. Inflammation 36: 169-176.

Prasad NR, Menon VP, Vasudev V, Pugalendi KV (2005) Radioprotective effect of sesamol on gammaradiation induced DNA damage, lipid peroxidation and antioxidants levels in cultured human lymphocytes. Toxicology 209(3):225-235.

Reza HM, Rahman MM, Ullah MO (2016) Hydroxycinnamic acid derivatives: a potential class of natural compounds for the management of lipid metabolism and obesity. NutrMetab (Lond).13:27.

Rosa LS, Jordão NA, da Costa Pereira Soares N, deMesquita JF, Monteiro M, Teodoro AJ (2018)Pharmacokinetic, Antiproliferative and Apoptotic Effects of Phenolic Acids in Human Colon Adenocarcinoma Cells Using In Vitro and In Silico Approaches Molecules 23:2569.

Sabitha R, Nishi K, Gunasekaran VP, Annamalai G, Agilan B, Ganeshan M(2019) p-Coumaric acid ameliorates ethanol-induced kidney injury by inhibiting inflammatory cytokine production and $\mathrm{NF}-\mathrm{KB}$ signaling in rats. Asian Pac J Trop Biomed 9:188-95.

Sachse, C. and E. Henkel (1996). "evaluation of the CELL-DYN 1700 haematologyanalyser: automated cell counting and three-part leucocyte differentiation." Clin Lab Haematol 18(3): 171-80. 
Saha S, Buttari B, Panieri E, Profumo E, Saso L (2020) An Overview of Nrf2 Signaling Pathway and Its Role in Inflammation. Molecules 25:5474.

Silva JDPD, Ballejo G. (2019) Pharmacological characterization of the calcium influx pathways involved in nitric oxide production by endothelial cells. Einstein (Sao Paulo) 17:eA04600.

Smith TA, Kirkpatrick DR, Smith S, Smith TK, Pearson T, Kailasam A, Herrmann KZ, Schubert J, Agrawal DK (2017) Radioprotective agents to prevent cellular damage due to ionizing radiation. J Transl Med 15: 232.

Srinivasan M, Sudheer AR, Pillai KR, Kumar PR, Sudhakaran PR, Menon VP (2007) Modulatory effects of curcumin on $y$-radiation-induced cellular damage in primary culture of isolated rat hepatocytes. Environ ToxicolPharmacol 24:98-105.

Takahashi N, Misumi M, Niwa Y, Murakami H, Ohishi W, Inaba T, Nagamachi A, Tanaka S, Braga Tanaka I, Suzuki G (2020) Effects of Radiation on Blood Pressure and Body Weight in the Spontaneously Hypertensive Rat Model. Are Radiation Effects on Blood Pressure Affected by Genetic Background? Radiat Res 193:552-559.

Taqi AH ,Faraj K ,Zaynal S, Said J ,Hameed A(2019)Effects of High Doses of X-Ray on Hematological Parameters and Morphology of Red Blood Cells in Human Blood. Iranian journal of medical physics 16: 112-119.

Tsai TH, Yu CH, Chang YP, Lin YT, Huang CJ, Kuo YH, Tsai PJ (2017) Protective Effect of Caffeic Acid Derivatives on tert-Butyl Hydroperoxide-Induced Oxidative Hepato-Toxicity and Mitochondrial Dysfunction in HepG2 Cells. Molecules 22:702.

Vucić V, Isenović ER, Adzić M, Ruzdijić S, Radojcić MB. (2006) "Effects of gamma-radiation on cell growth, cycle arrest, death, and superoxide dismutase expression by DU 145 human prostate cancer cells." Brazilian Journal of Medical and Biological Research 39: 227-236.

Weissman BA, Jones CL, Liu Q, Gross SS. (2002) Activation and inactivation of neuronal nitric oxide synthase: characterization of $\mathrm{Ca}^{2+}$-dependent calmodulin binding. Eur J Pharmacol 435: 9-18.

Wilson A, Menon V, Khan Z, Alam A, Litovchick L, Yakovlev V (2019) Nitric oxide-donor/PARP-inhibitor combination: A new approach for sensitization to ionizing radiation. Redox Biol 24:101169.

Yahyapour R, Shabeeb D, Cheki M, Musa AE, Farhood B, Rezaeyan A, Amini P, Fallah H, Najafı M (2018) Radiation Protection and Mitigation by Natural Antioxidants and Flavonoids: Implications to Radiotherapy and Radiation Disasters. CurrMolPharmacol 11:285-304.

Yıldızhan K., Demirtaş, Ö C, Uyar, A, Huyut Z, Çakir T, Keleş Ö F, \&Yener Z. (2020) Protective effects of Urticadioica L. seed extract on liver tissue injury and antioxidant capacity in irradiated rats. Brazilian 
Journal of Pharmaceutical Sciences 56:e18354. Epub March 16, 2020.

Yoshioka T, Kawada K, Shimada T, Mori M (1979) "lipid peroxidation inmaternal and cord blood and protective mechanism against activated oxygen toxicity in the blood." Am J ObstetGynecol 135: 372-376.

Zavodnik LB, Kravchuk RI, Artsukevich AN, Chumachenko SS, Sheĭbak VM, Ovchinnikov VA, Buko VU (2003) DinamikastrukturnykhizmeneniǏ v pechenikrysposleodnokratnogovozdelstviia gamma-izlucheniia [Dynamics of structural changes in rat liver after single dose of gamma-irradiation]. RadiatsBiolRadioecol 43:618-24.

Zeb A (2020) Concept, mechanism, and applications of phenolic antioxidants in foods. J Food Biochem 44:e1339.

\section{Tables}

Table (1): Effect of ZCoNPs+ZCaNPs and/or IR on the body weight (gm) and number of death in the different groups.

\begin{tabular}{c|cccc} 
Groups & Control & ZCoNPs+ZCaNPs & IR & IR + ZCoNPs+ZCaNPs \\
\hline Parameters & & & & \\
\hline N & 8 & 8 & 8 & 8 \\
D & & - & 4 & ---
\end{tabular}

\begin{tabular}{l|llll}
$\begin{array}{l}\text { Body } \\
\text { weight }\end{array}$ & $129 \pm 16$ & $137 \pm 3.6$ & $114 \pm 1.8^{\text {a1 }}$ & $136 \pm 1.8^{\text {b3 }}$
\end{tabular}

(6)

$(-12)$

(5)

All values are expressed as means $\pm S D(n=8)$. Values between brackets show the percentage of change from Control. a: significance vs. control group. b: significance vs. irradiated (IR) group. Differences between means were considered significant a1 at $p \leq$ .05 , a2 highly significant at $p \leq .01$ and very highly significant a3 at $p \leq .001$. (N) Number of live rats (D) Number of dead rats. 
Table (2): Effect of ZCoNPs+ZCaNPs and/or IR on the complete blood count level in the different groups.

\begin{tabular}{|c|c|c|c|c|}
\hline Parameters Groups & Control & $\begin{array}{c}\text { ZCoNPs+Z } \\
\text { CaNPs }\end{array}$ & IR & IR + ZCoNPs+ZCaNPs \\
\hline \multirow[t]{2}{*}{ WBC (K/uL) } & $8.7 \pm 0.2$ & $8.2 \pm 0.2$ & $1.3 \pm 0.2^{\mathrm{a} 3}$ & $7.4 \pm 0.05^{\mathrm{a} 1 \mathrm{~b} 3}$ \\
\hline & & $(-6)$ & $(-85)$ & $(-15)$ \\
\hline \multirow[t]{2}{*}{ LYM (RM) } & $2.9 \pm 0.5$ & $2.8 \pm 0.1$ & $0.5 \pm 0.01^{\mathrm{a} 3}$ & $2.3 \pm 0.5^{\mathrm{a} 2 \mathrm{~b} 3}$ \\
\hline & & $(-3)$ & $(-100)$ & $(-20)$ \\
\hline \multirow[t]{2}{*}{ LYM (\% L) } & $44 \pm 3.9$ & $45.2 \pm 4.9$ & $10 \pm 1.2^{\text {a } 3}$ & $43 \pm 4.3^{\mathrm{b} 3}$ \\
\hline & & (3) & $(-77)$ & $(-2)$ \\
\hline \multirow[t]{2}{*}{ MID (Monocyte) } & $0.80 \pm 0.0$ & $0.77 \pm 0.0$ & $0.2 \pm 0.01^{\mathrm{a} 3}$ & $0.70 \pm 0.05^{\mathrm{a} 1 \mathrm{~b} 3}$ \\
\hline & & 0 & $(-75)$ & $(-13)$ \\
\hline \multirow[t]{2}{*}{ MID (Monocyte \%M) } & $6.9 \pm 0.0$ & $6.9 \pm 0.0$ & $1.3 \pm 0.2^{\mathrm{a} 3}$ & $6.8 \pm 1.9^{b 3}$ \\
\hline & & 0 & $(-81)$ & $(-1)$ \\
\hline \multirow[t]{2}{*}{ GRAN (RM) } & $4 \pm 1.4$ & $3.7 \pm 1.3$ & $0.5 \pm 0.6^{\mathrm{a} 3}$ & $3.0 \pm 1.1^{\mathrm{a} 2 \mathrm{~b} 3}$ \\
\hline & & $(-8)$ & $(-87)$ & $(-25)$ \\
\hline \multirow[t]{2}{*}{ GRAN (\%G) } & $50.7 \pm 5.2$ & $52.4 \pm 7.5$ & $2 \pm 0.1^{\mathrm{a} 3}$ & $40.2 \pm 4.1^{\mathrm{a} 1 \mathrm{~b} 3}$ \\
\hline & & $(3)$ & $(-96)$ & (11) \\
\hline \multirow[t]{2}{*}{ RBC (M/uL) } & $5.2 \pm 0.08$ & $5.4 \pm 0.08$ & $3 \pm 0.05^{a 3}$ & $4.5 \pm 0.09^{\mathrm{a} 1 \mathrm{~b} 3}$ \\
\hline & & (4) & $(-42)$ & $(-13)$ \\
\hline \multirow[t]{2}{*}{ HGB $(g / d L)$} & $13.7 \pm 0.7$ & $13.6 \pm 0.8$ & $4.6 \pm 0.8^{\mathrm{a} 3}$ & $12.9 \pm 2.6^{\mathrm{b} 3}$ \\
\hline & & $(-0.7)$ & $(-66)$ & $(-6)$ \\
\hline \multirow[t]{2}{*}{ НСТ \% } & $41.6 \pm 3.8$ & $42.4 \pm 3.7$ & $18.8 \pm 1.7$ a3 & $41.1 \pm 3.7^{\mathrm{b} 3}$ \\
\hline & & (2) & $(-55)$ & $(-1)$ \\
\hline \multirow[t]{2}{*}{$M C V(f L)$} & $89 \pm 7$ & $88 \pm 8$ & $48 \pm 4.9^{\mathrm{a} 3}$ & $80 \pm 8^{\mathrm{b} 3}$ \\
\hline & & $(-0.1)$ & $(-46)$ & $(-10)$ \\
\hline \multirow[t]{2}{*}{$\mathrm{MCH}(\mathrm{pg})$} & $29.3 \pm 2.7$ & $28.9 \pm 0.7$ & $15.2 \pm 1.8$ a3 & $25.1 \pm 1.6^{\mathrm{a} 1 \mathrm{~b} 3}$ \\
\hline & & $(-1)$ & $(-48)$ & $(-14)$ \\
\hline \multirow[t]{2}{*}{$\mathrm{MCHC}(\mathrm{g} / \mathrm{dL})$} & $33.6 \pm 2.4$ & $33.4 \pm 0.3$ & $38.9 \pm 1.6$ a3 & $33.8 \pm 2.4^{\mathrm{b} 3}$ \\
\hline & & $(-1)$ & (16) & (1) \\
\hline \multirow[t]{2}{*}{ RDW \% } & $13 \pm 1.1$ & $12.7 \pm 0.7$ & $4.1 \pm 0.7^{\mathrm{a}^{3}}$ & $12.6 \pm 1.8^{\mathrm{b} 3}$ \\
\hline & & $(-2)$ & $(-69)$ & $(-3)$ \\
\hline \multirow[t]{2}{*}{ PLT (K/uL) } & $293 \pm 57$ & $294 \pm 49$ & $111 \pm 23^{a 3}$ & $291 \pm 50^{\mathrm{b} 3}$ \\
\hline & & $(0.2)$ & $(-61)$ & $(-0.5)$ \\
\hline
\end{tabular}

All values are expressed as means $\pm S D(n=8)$. ). Values between brackets show the percentage of change from Control. Values marked with letters are significantly different ( $a 1: p \leq 0.05, a 2: p \leq 0.01, a 3: p \leq 0.001$ [significance vs. control group]; b1: $p \leq 0.05, b 2: p \leq 0.01, b 3: p \leq 0.001$ [significance vs. irradiated group (IR)] 
Table 3: Different effects of ZCoNPs+ZCaNPs and/or IR on DNA fragmentation level in liver tissues in the different groups

\begin{tabular}{|c|c|c|c|c|}
\hline Groups & Control & ZCoNPs+ZCaNPs & IR & IR+ ZCoNPs+ZCaNPs \\
\hline \multirow[t]{2}{*}{ Tail Length $\mu \mathrm{m}$} & $0.3 \pm 0.6$ & 0 & $84.5 \pm 4.5^{\mathrm{a} 3}$ & $0.3 \pm 0.6$ \\
\hline & & $(-100)$ & $(28066)$ & $(0)$ \\
\hline \multirow[t]{2}{*}{ DNA in Tail } & $0.8 \pm 1.3$ & $0.04 \pm 0.004$ & $3.1 \pm 1.3^{\mathrm{a} 3}$ & $0.04 \pm 0.006^{\mathrm{a} 3 \mathrm{~b} 3}$ \\
\hline & & $(-95)$ & (288) & $(-95)$ \\
\hline \multirow[t]{2}{*}{ Tail Moment } & 0 & 0 & $2.5 \pm 1^{\mathrm{a} 3}$ & 0 \\
\hline & & (0) & $(250)$ & (0) \\
\hline \multirow[t]{2}{*}{ Olive Moment } & $0.007 \pm 0.1$ & 0 & $1.4 \pm 0.7^{\mathrm{a} 3}$ & 0 \\
\hline & & $(-100)$ & (19900) & $(-100)$ \\
\hline
\end{tabular}

All values are expressed as means $\pm \mathrm{SD}(n=8)$. ). Values between brackets show the percentage of change from Control. Values marked with letters are significantly different (a1: $p \leq 0.05, \mathrm{a} 2: p \leq 0.01, \mathrm{a} 3: p \leq 0.001$ [significance vs. control group]; b1: $p \leq$ $0.05, \mathrm{~b} 2: p \leq 0.01, \mathrm{~b} 3: p \leq 0.001$ [significance vs. irradiated group (IR)] 
Table (4): Effects of ZCoNPs+ZCaNPs and/or IR on the activity of superoxide dismutase, glutathione peroxidise, catalase, glutathione content, lipid peroxidation, total free radicals concentrate and total nitric oxide in different groups.

\begin{tabular}{|c|c|c|c|c|}
\hline Parameters Groups & Control & ZCoNPs+ZCaNPs & IR & IR + ZCoNPs+ZCaNPs \\
\hline SOD $(\mu \mathrm{g} / \mathrm{ml})$ & $4.3 \pm 1.3$ & $\begin{array}{c}5.4 \pm 0.4^{32} \\
(26)\end{array}$ & $\begin{array}{c}0.9 \pm 0.3^{a 3} \\
(-79)\end{array}$ & $\begin{array}{c}3.8 \pm 0.7^{-163} \\
(-12)\end{array}$ \\
\hline GSH (mg/mol) & $38.5 \pm 4$ & $\begin{array}{c}41.4 \pm 3.1 \\
\text { (8) }\end{array}$ & $\begin{array}{c}10.8 \pm 1.6^{33} \\
(-72)\end{array}$ & $\begin{array}{c}39.1 \pm 3.9^{\mathrm{b} 3} \\
\text { (2) }\end{array}$ \\
\hline GPx $(\mathrm{min} / \mathrm{ml})$ & $7.1 \pm 1.2$ & $\begin{array}{c}7.5 \pm 0.2^{d} \\
(6)\end{array}$ & $\begin{array}{c}1.9 \pm 0.1^{a 3} \\
(-73)\end{array}$ & $\begin{array}{c}6.2 \pm 0.2^{\mathrm{a1b3}} \\
(-13)\end{array}$ \\
\hline CAT $(\mu \mathrm{mol} / \mathrm{ml})$ & $5.8 \pm 1.1$ & $\begin{array}{c}7.1 \pm 0.2^{\mathrm{a}} \\
(22)\end{array}$ & $\begin{array}{l}4 \pm 0.2^{23} \\
(-31)\end{array}$ & $\begin{array}{c}6 \pm 0.5^{\mathrm{b} 3} \\
\text { (3) }\end{array}$ \\
\hline LP $(\mathrm{mM} / \mathrm{L})$ & $1.7 \pm 0.2$ & $\begin{array}{c}1.6 \pm 0.1 \\
(-6)\end{array}$ & $\begin{array}{c}3 \pm 0.09^{a 3} \\
(+76)\end{array}$ & $\begin{array}{c}1.9 \pm 0.1^{11 \mathrm{~b} 3} \\
(12)\end{array}$ \\
\hline NOx $(\mu \mathrm{mol} / \mathrm{L})$ & $23.6 \pm 2.9$ & $\begin{array}{c}20.9 \pm 2.3^{a 1} \\
(-11)\end{array}$ & $\begin{array}{c}36.3 \pm 3.2^{\text {a3 }} \\
(54)\end{array}$ & $\begin{array}{c}28.7 \pm 3.9^{\mathrm{a}^{2 \mathrm{~b} 3}} \\
(+22)\end{array}$ \\
\hline TFRC(Radicals/g) $\times 10^{17}$ & $0.48 \pm 0.01$ & $\begin{array}{c}0.44 \pm 0.01 \\
(-8)\end{array}$ & $\begin{array}{c}4.1 \pm 0.3^{\text {a3 }} \\
(754)\end{array}$ & $\begin{array}{c}0.47 \pm 0.02^{\mathrm{b} 3} \\
(-2)\end{array}$ \\
\hline
\end{tabular}

All values are expressed as means \pm SD $(n=8)$. ). Values between brackets show the percentage of change from Control. Values marked with letters are significantly different (a1: $p \leq 0.05, \mathrm{a} 2: p \leq 0.01, \mathrm{a} 3: p \leq 0.001$ [significance vs. control group]; $\mathrm{b} 1: p \leq$ 0.05 , b2: $p \leq 0.01$, b3: $p \leq 0.001$ [significance vs. irradiated group (IR)] 
Table (5): Different effects of ZCoNPs+ZCaNPs and/or IR on T helper cells (CD4) and T cytoxic cells (CD8) expression in the different groups.

\begin{tabular}{|c|c|c|c|c|}
\hline Groups & Control & ZCoNPs+ZCaNPs & IR & IR + ZCoNPs+ZCaNPs \\
\hline \multirow[t]{2}{*}{ CD4 } & $49.9 \pm 4.8$ & $50 \pm 1.9$ & $18.2 \pm 1.3^{\mathrm{a} 3}$ & $40.9 \pm 3.8^{\mathrm{a} 1 \mathrm{~b} 3}$ \\
\hline & & $(0.2)$ & $(-64)$ & $(-18)$ \\
\hline \multirow[t]{2}{*}{ CD8 } & $12.5 \pm 1.9$ & $13.8 \pm 3.4$ & $4.5 \pm 0.4$ a3 & $10.5 \pm 2.2^{\mathrm{a} 1 \mathrm{~b} 3}$ \\
\hline & & (10) & $(-64)$ & $(-16)$ \\
\hline
\end{tabular}

All values are expressed as means \pm SD $(n=8)$. ). Values between brackets show the percentage of change from Control. Values marked with letters are significantly different (a1: $p \leq 0.05, \mathrm{a} 2: p \leq 0.01, \mathrm{a} 3: p \leq 0.001$ [significance vs. control group]; $\mathrm{b} 1: p \leq$ 0.05 , b2: $p \leq 0.01$, b3: $p \leq 0.001$ [significance vs. irradiated group (IR)] 
Table (6): Different effects of ZCoNPs+ZCaNPs and/or IR on cell cycle phases in the different groups.

\begin{tabular}{|c|c|c|c|c|}
\hline Groups & Control & ZCoNPs+ZCaNPs & IR & $\mathrm{IR}+\mathrm{ZCoNPs}+\mathrm{ZCaNPs}$ \\
\hline \multirow[t]{2}{*}{ Sub G1(Apoptosis) } & $41.3 \pm 4.6$ & $23 \pm 3.6^{\mathrm{a} 3}$ & $8.2 \pm 1^{\mathrm{a} 3}$ & $33.4 \pm 4.2^{\mathrm{a} 1 \mathrm{~b} 3}$ \\
\hline & & $(-44)$ & $(114)$ & $(-19)$ \\
\hline \multirow[t]{2}{*}{ Go/1 } & $38 \pm 3.3$ & $43.7 \pm 3.8^{\mathrm{a} 1}$ & $8.1 \pm 0.8^{\mathrm{a} 3}$ & $37.4 \pm 4.7^{\mathrm{b} 3}$ \\
\hline & & (15) & $(-79)$ & $(-2)$ \\
\hline \multirow[t]{2}{*}{$\mathbf{S} \%$} & $11.1 \pm 1.0$ & $21.8 \pm 3.1^{\mathrm{a} 3}$ & $0.5 \pm 0.07$ a3 & $18.2 \pm 2.1^{\mathrm{a} 3 \mathrm{~b} 3}$ \\
\hline & & (96) & $(-96)$ & (64) \\
\hline \multirow[t]{2}{*}{ G2/M \% } & $4.2 \pm 0.3$ & $4.0 \pm 1.2$ & $13.6 \pm 2.7$ a3 & $3.6 \pm 1^{\mathrm{a} 1 \mathrm{~b} 3}$ \\
\hline & & $(-5)$ & $(224)$ & $(-14)$ \\
\hline
\end{tabular}

All values are expressed as means $\pm S D(n=8)$. ). Values between brackets show the percentage of change from Control. Values marked with letters are significantly different (a1: $p \leq 0.05$, a2: $p$ $\leq 0.01$, a3: $p \leq 0.001$ [significance vs. control group]; b1: $p \leq 0.05$, b2: $p \leq 0.01$, b3: $p \leq 0.001$ [significance vs. irradiated group (IR)

\section{Figures}



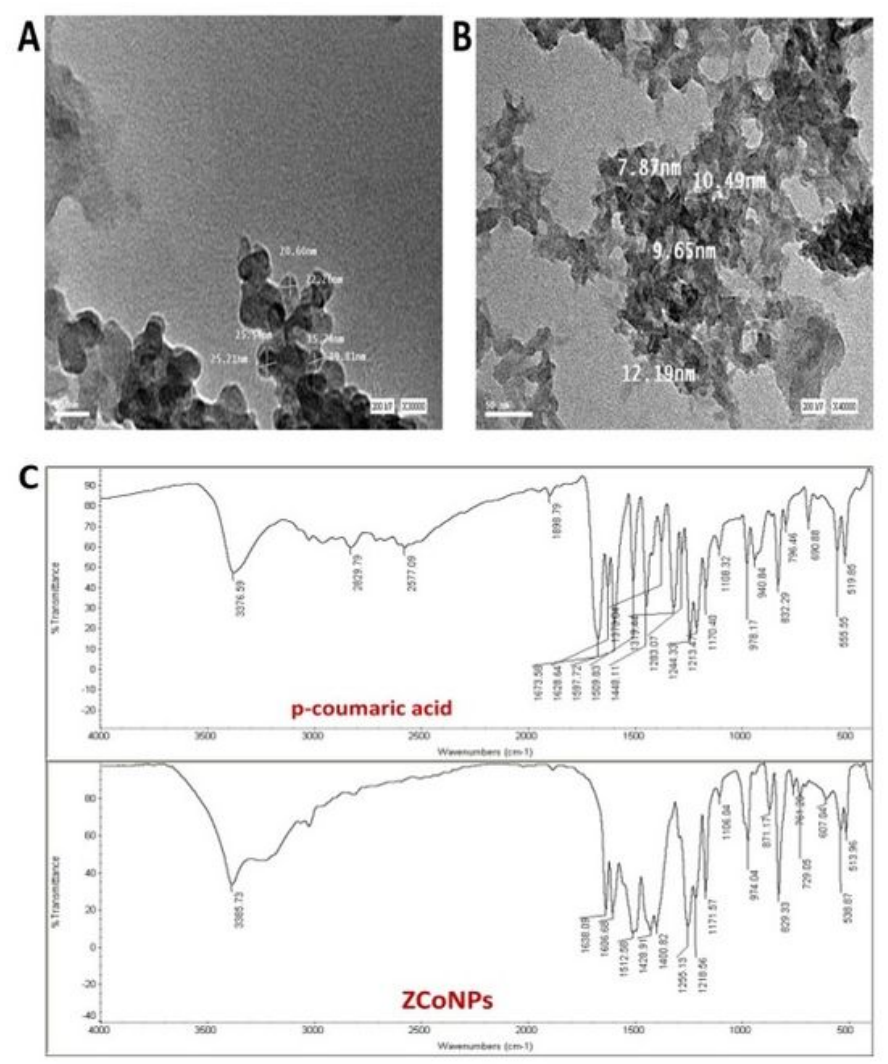

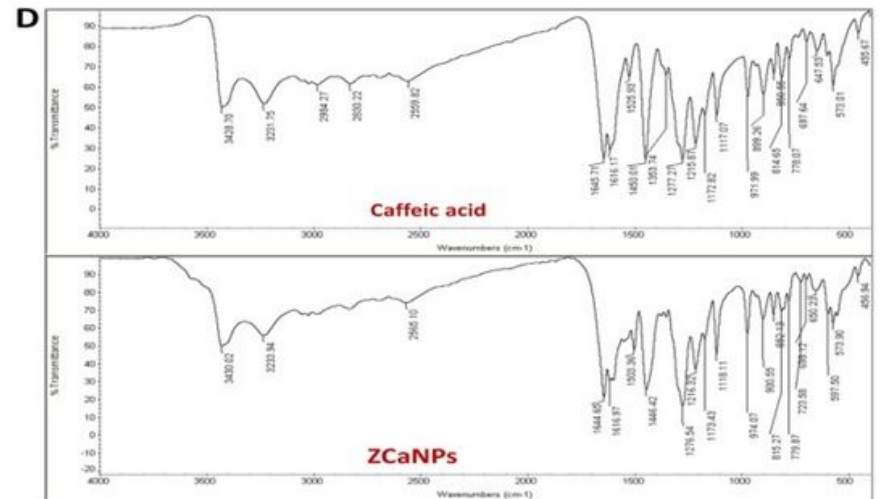

E

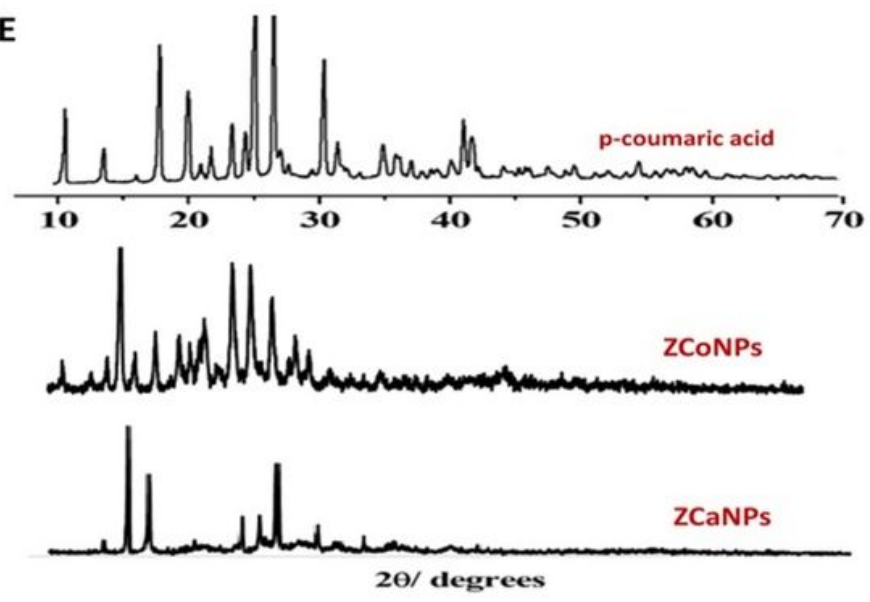

\section{Figure 1}

Transmission electron microscope image of the ZCoNPs (A), ZCaNPs (B). FTIR spectrum of p-coumaric acid and ZCoNPs (C) and Caffeic acid and ZCaNPs (D). XRD patterns of p-coumaric acid, ZCoNPs and ZCaNPs (E).

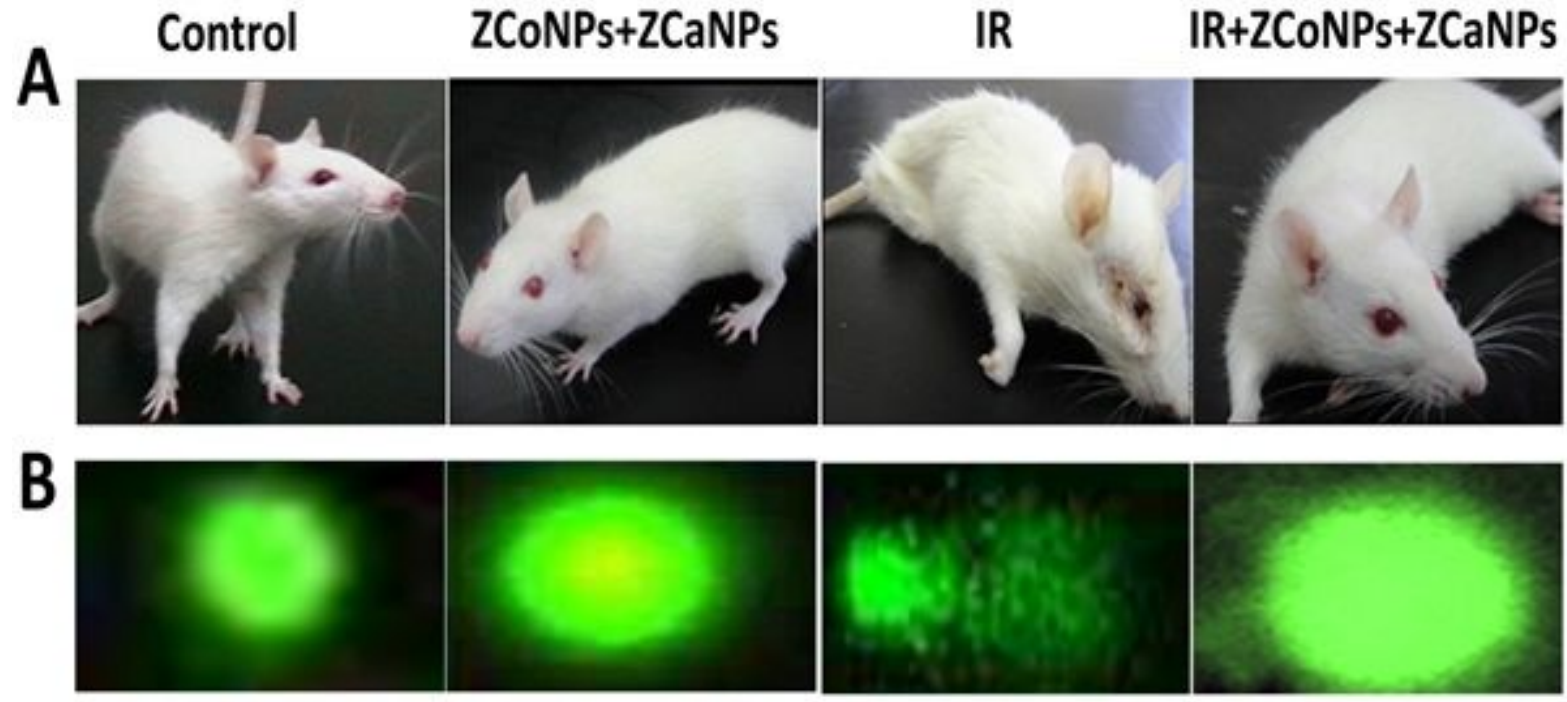

Figure 2 
Effect of ZCoNPs+ZCaNPs and/or IR on the morphological state (A) and DNA fragmentation in live tissues (B) in the different animal groups.

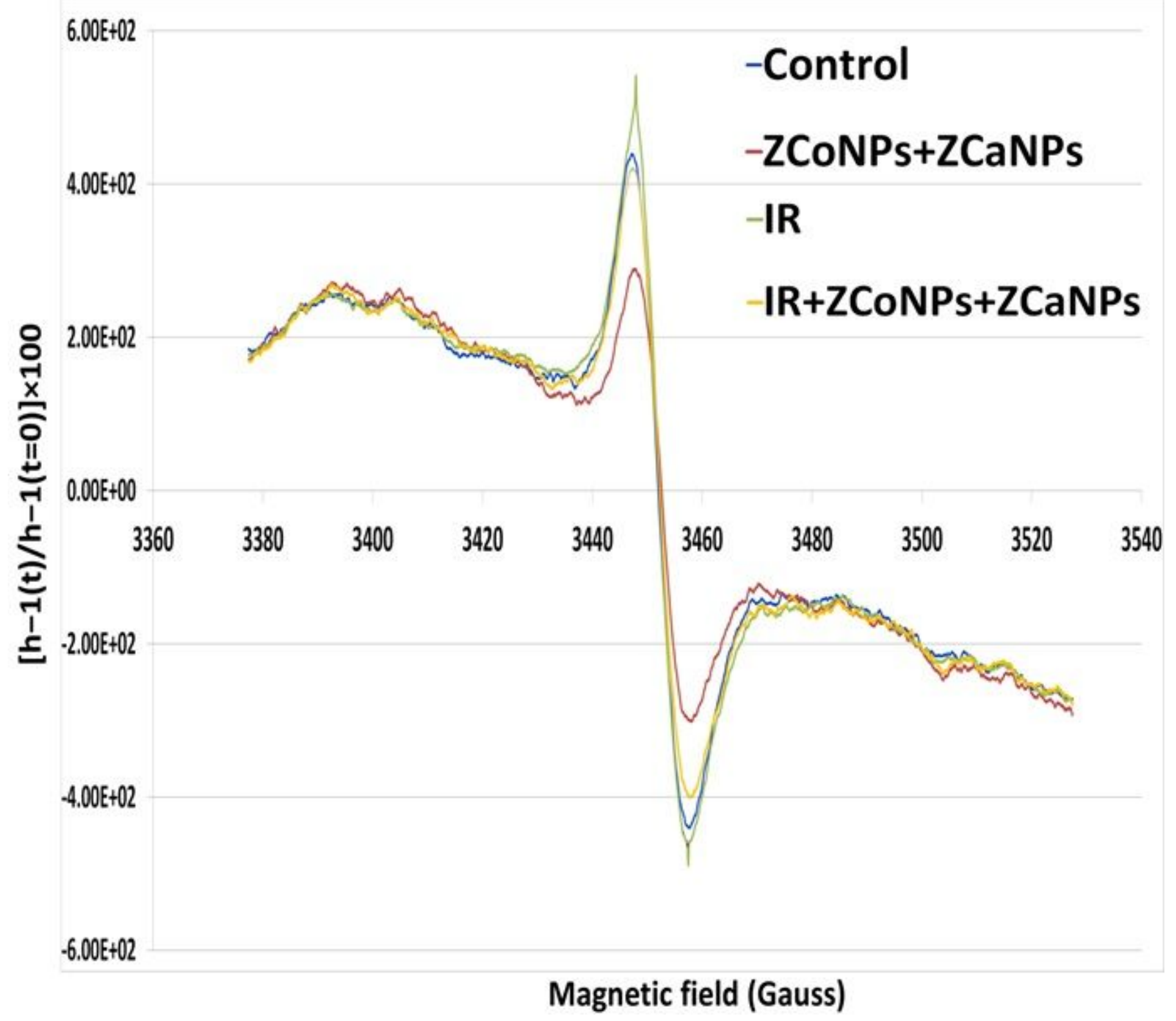

Figure 3

Effect of ZCoNPs+ZCaNPs and/or IR on the level of total free radicals in the different groups. 

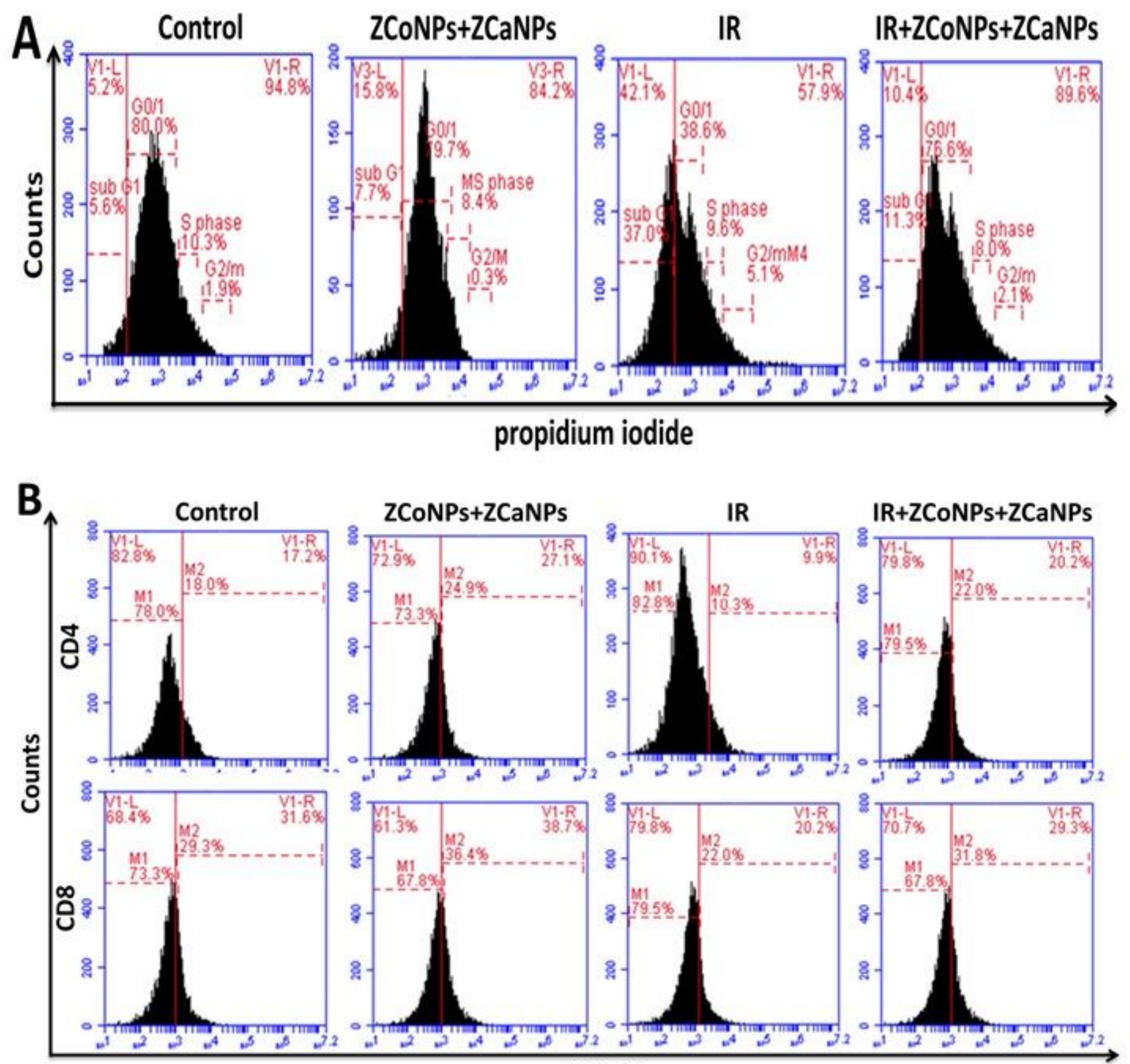

FL 1-H

Figure 4

Effect of ZCoNPs + ZCaNPs and/or IR on the cell cycle phases (A), and expression of T helper cells; CD4 and T cytoxic cells; CD8 (B) in the different groups. Samples were analysis triplicate. 

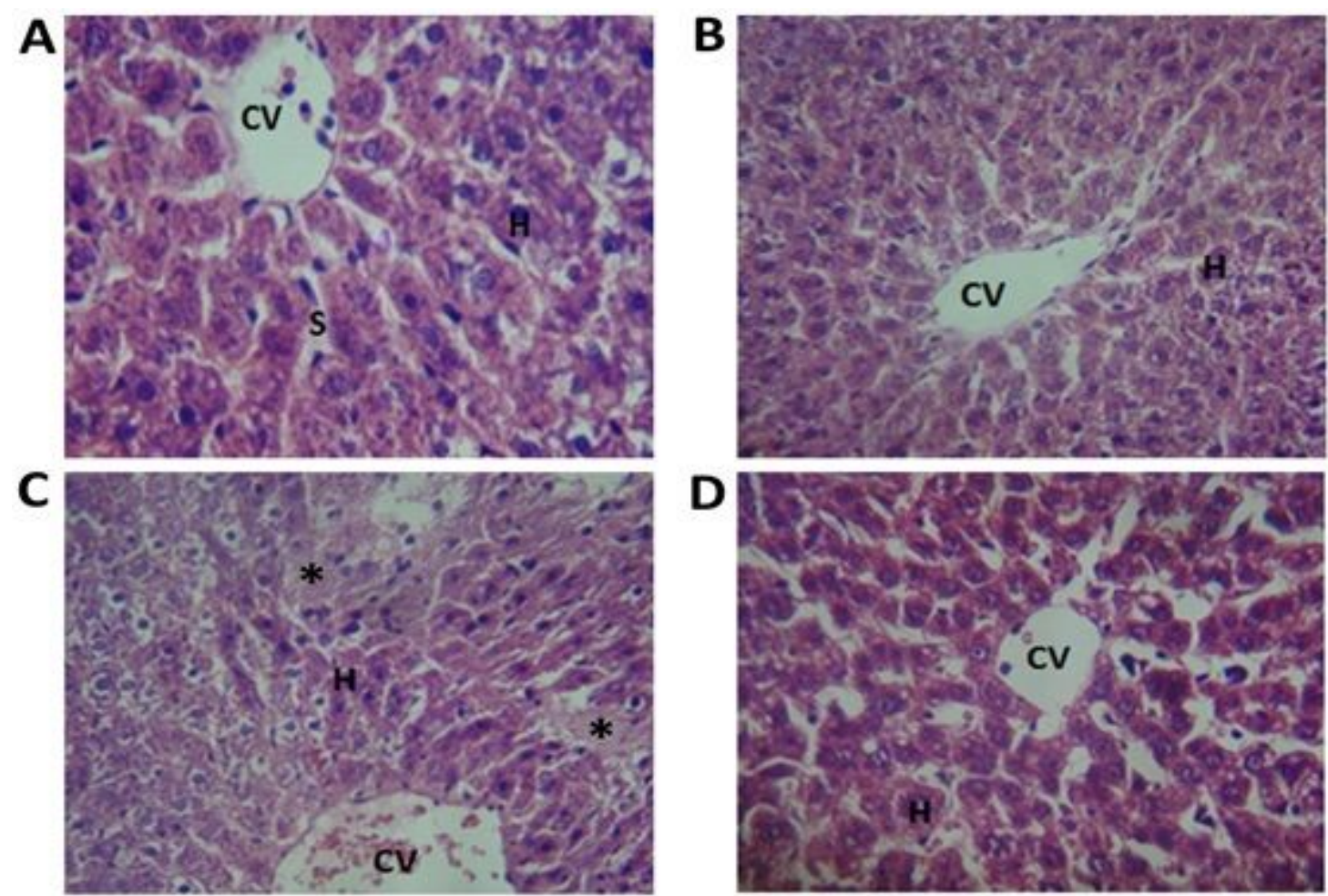

\section{Figure 5}

Effect of ZCoNPs+ZCaNPs and/or IR on histopathological changes of hepatocytes; (A) Light photomicrography of liver of a control rat showing the hepatocytes $(H)$ are arranged into hepatic cords running radiantly from the central vein (CV) and are separated by adjacent blood sinusoids (S) containing Kupffer cells. (B) Liver of rats treated with ZCoNPs+ZCaNPs alone showing normal appearance of liver lobular architecture with central vein (CV). (C) Liver of irradiated rat showing the cellular structure of the liver tissues. The hepatocyte cytoplasm is light, foamy and filled with vacuoles; cell sizes are enlarged, nuclear chromatin is more condensed. Odema areas $(*)$ were observed. (D) Liver of rat of IR + ZCoNPs+ZCaNPs group Showing normal lobular architecture with central vein and radiating hepatic liver. $H \& E, x 400$. 